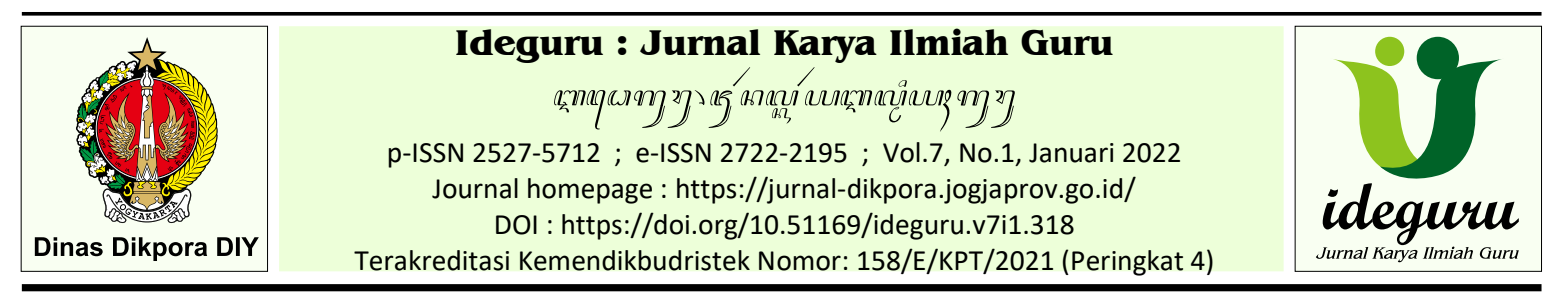

Artikel Penelitian - Naskah dikirim: 18/10/2021 - Selesai revisi: 01/12/2021 - Disetujui: 02/12/2021 - Diterbitkan: $01 / 01 / 2022$

\title{
Pengembangan Desain Blended Learning Mata Pelajaran Fisika SMA pada Era Kenormalan Baru
}

\author{
Rita Nunung Tri Kusyanti \\ SMA Negeri 1 Tempel, Sleman, Daerah Istimewa Yogyakarta, Indonesia \\ trikusyanti3@gmail.com
}

\begin{abstract}
Abstrak: Tujuan penelitian ini untuk mengembangkan desain pembelajaran blended learning pada mata pelajaran Fisika kelas XI di masa era kenormalan baru. Penelitian ini adalah penelitian pengembangan R\&D dengan model ADDIE. Tahapan penelitian ini, hanya sampai pada tahapan kedua yaitu analisis kebutuhan dan desain rancangan model pembelajaran blended. Teknik pengumpulan data menggunakan lembar observasi untuk memvalidasi rancangan (brief design) pembelajaran blended, instrumen penelitian berupa lembar observasi, analisa data secara kualitatif. Perencanaan desain produk dengan menyusun desain pembelajaran blended dengan mengacu pada kompetensi matapelajaran Fisika pada masa darurat C-19 dengan sintak blended learning. Berdasar analisis kebutuhan pembelajaran blended learning paling efektif untuk diterapkan pada era kenormalan baru. Desain pembelajaran (brief design) blended learning Fisika model flipped classroom dengan memperhatikan variasi tatap muka pembelajaran offline dan pembelajaran online dengan prosentasi 50\%-50\%. Hasil validasi ahli media dan materi diperoleh penilaian obyek pembelajaran mengadaptasi dari LORI adalah adalah $81,58 \%$ masuk kategori setuju dan $85,52 \%$ masuk kategori sangat setuju, kuesioner evaluasi proses pembelajaran daring adalah 81,25 \% masuk kategari cukup baik, dan 89,58\% masuk kategori sangat baik, penilaian desain pembelajaran blended learning adalah 85\% masuk kategari setuju dan 90\% masuk kategori sangat setuju. Rerata aspek atau indikator 85,48\% maka hasil validasi ahli isi materi dan media desain pembelajaran blended yang dikembangkan bisa diuji cobakan karena sudah memasuki klasifikasi baik (mendekati sangat baik).
\end{abstract}

Kata kunci: blended learning; flipped classroom; masa era kernormalan baru.

\section{Blended Learning Design Development at Physics Courses in the New Normality Era}

\begin{abstract}
This study aims to develop a blended learning design for class XI physics subjects in the new normal era. This research is a form of $R \& D$ research with the ADDIE (Analysis, Design, Development, Implementation and Evaluation) model. In this study, researchers only arrived at the second stage, namely needs analysis and design of blended learning model designs. Data collection techniques used observation sheets to validate the blended learning design, research instruments in the form of observation sheets, qualitative data analysis. Product design planning by compiling blended learning designs with reference to the competence of physics subjects in the C-19 emergency period with blended learning syntax. Based on the analysis of learning needs, blended learning is the most effective to be applied in the new normal era. The learning design (brief design) blended learning physics with the flipped classroom model by paying attention to face-to-face variations of offline learning and online learning with a percentage of 50\%-50\%. The results of the validation of media and material experts obtained that the assessment of the learning object to adapt from the LORI was 8543.53\%; 86, 84\% fall into the category of strongly agree., the online learning process evaluation questionnaire through blended learning design is $81,25 \%$ in the fairly good category; $89.58 \%$ is in the very good category. The questionnaire for the assessment of blended learning is $85 \%$ in the quite good category; $90 \%$ fall into the very good category. Based on the conversion table and qualifications can be obtained that the average aspect or indicators $85,48 \%$, then the results of expert validation material content and media developed blended learning design can be tested as they had been very good classification.
\end{abstract}

Keywords: blended learning; flipped classroom; the era of the new normal.

\section{Pendahuluan}

Panduan pembelajaran pada masa pandemi Covid-19 untuk jenjang sekolah menegah atas telah dikeluarkan oleh empat kementerian yaitu
Kemenkes, Kemendikbudristek, Kemenag dan Kemendagri. Berkaitan dengan kurikulum yang disederhanakan, sekolah mengatur sistem Pembelajaran Tatap Muka Terbatas atau PTMT, 
misalnya dalam satu kelas yang masuk 50\% dari siswa. Sekolah juga harus menyiapkan materi mana yang harus diajarkan saat PTM terbatas dan materi mana yang harus dikerjakan saat anakanak di rumah.

Hal ini merupakan tantangan tersendiri bagi kami guru di sekolah menengah atas, dengan mengingat kondisi yang ada, mau tidak mau guru harus menyiapkan diri untuk merancang, mendesain pembelajaran tatap muka (PTM) terbatas pada era kenormalan baru. Tugas guru dalam pembelajaran adalah merencanakan, melaksanakan, mengendalikan, menilai, mengevaluasi, memproses dan mengelola hasil belajar. Dengan sistem pembelajaran pada era kenormalan baru, menggunakan strategi yang memadukan pembelajaran dengan pendekatan asinkron dengan pembelajaran tatap muka terbatas, merupakan solusi efektifitas, aman dan efisien sehingga diharapkan proses hasil belajar dapat dicapai dengan maksimum.

Pembelajaran dengan Blended learning adalah perpaduan yang efektif anatar berbagai macam metode pembelajaran dan gaya pembelajaran yang dapat digunakan secara daring dan luring, baik di dalam kelas atau saat siswa belajar dirumah (Oktaria dkk, 2018: 7). Pembelajaran blended dalam konteks Sistem Pembelajaran Daring Indonesia (SPADA) adalah suatu bentuk pembelajaran yang memadukan pembelajaran sinkron dan asinkron dalam kerangka membuat pengalaman baru sehingga tujuan pembelajaran tercapai hasil yang memuaskan (Kemenristekdikti, 2017: 12).

ICT dari sudut pandang pedagogik menjadi strategis dan diperlukan dalam kegiatan belajar mengajar. Pemanfaatan TIK dalam pedagogik menerapkan empat pilar pendidikan yaitu learning to know, learning to do, learning to live together, dan learning to be (Dewi. K.C dkk: 2018: 12).

Penggunaan blended learning mempunyai manfaat yang baik terhadap kegiatan belajar mengajar, siswa merasakan manfaatnya, terdapat berbagai kelemahan dan kelebihan yang saling melengkapi antara pembelajaran tatap muka dan pembelajaran dalam jaringan online (Alammary, 2019). Penerapan model pembelajaran Blended learning memberikan pengalaman lebih kepada siswa antara lain siswa lebih sering membuka, mengundhuh modul atau materi pembelajaran sehingga mutu pembelajaran lebih baik, dan dapat menurunkan anggaran belajar siswa (Stein \& Graham, 2014: 14).

Menurut Smythe (2011) aspek-aspek utama dari blended learning adalah (a) aspek mode delivery yaitu kombinasi konvensional atau tradisional learning dengan pendekatan aplikasi yang berbasis web atau web based online, (b) aspek teknologi yaitu penggunaan teknologi dan media (c) aspek strategi pembelajaran atau pedagogi yaitu perpaduan antara berbagai model pembelajaran, (c) aspek kronologi yaitu pendekatan synchronous adalah pendekatan pembelajaran yang memerlukan koneksi internet karena pembelajaran berinteraksi langsung, realtime dan komunikasi sudah dijadwalkan sebelumnya, misalnya mengerjakan kuis, video conference, chatting. dan asynchronous, siswa belajar melalui media pembelajaran dan dapat diakses dalam waktu tertentu tanpa ada batasana ruang dan waktu.

Dalam paradigma pembelajaran dalam jaringan, baik e-learning maupun blended learning, terdapat model-model kelas yang dapat digunakan, contohnya model (a) Model kelas Laboratorium yaitu siswa dapat berpindah dari satu ruang kelas ke ruang lainnya sesuai dengan waktu yang sudah terjadwal. Pada ruang tertentu terdapat kelas yang menggunakan jaringan internet atau pembelajaran dalam jaringan, sangat pas untuk siswa sekolah dasar. (b) Lab rotation mirip dengan model Station lab Namun, pada model ini pembelajaran menggunakan komputer di laboratorium sekolah dan wifi sekolah. Desian pembelajaran seperti ini disarankan untuk pendidikan vokasi, pendidikan berbasis keahlian, teknik, kedokteran, (c) Individual rotation: seperti moving class, siswa berpindah keruang yang lain saat berganti matapelajaran, (d) model flip classroom pembelajaran terbalik yaitu apa yng dikerjakan di kelas dapat dikerjakan di rumah, Siswa dapat belajar dari rumah secara online melalui platform pembelajaran online. Sehingga saat pertemuan tatap muka guru dapat mengelola pembelajarannya untuk merancang kegiatan yang dilakukan oleh siswa di rumah, diharapkan semua aktifitas kegiatan siswa terlibat (Student center learning). (e) flex classroom, siswa dapat berganti kegiatan belajaranya ke aktifitas lainnya disesuaikan dengan pembelajaran yang mereka perlukan. Pembelajaran daring (Online learning) merupakan inti dari dari model flex ini. Perintah diberikan guru sehingga siswa dapat mengerjakan aktifitas pembelajaran sesuai dengan kurikulum namun dengan jadwal yang fleksibel, (f) A La Carte, siswa dapat belajar langsung dengan guru dapat juga melalui media komputer, rekaman video (Handoko \& Waskito, 2018: 7-11). 
Penerapan blended learning adalah siklus yang meliputi perencanaan (planning) dari sekolah maupun dari guru mendesain pembelajaran dan media pembelajaran, pelaksanaan (doing), evaluasi (evaluating), dan merencanakan kembali (replanning).

Secara umum proses implementasi blended learning meliputi (a) rancangan pembelajaran (learning design) adalah suatu proses yang harus dilakukan, untuk pembelajaran tatap muka maupun pembelajaran secara daring untuk mencapai perilaku hasil belajar yang dikehendaki, menganalisa pembelajaran, cara apa yang akan digunakan dalam menyampaikan materi, materi pelajaran, serta penilaian hasil pembelajaran; (b) penyedian media pembelajaran (content production) /guru dapat membuata mandiri media pembelajaran sehingga dapat membantu siswa dalam proses belajar. Media pembelajaran tersebut dapat berupa slide presentasi, e-modul, video, audio, dan lainnya. Selain memproduksi sendiri, guru dapat menggunakan media pembelajaran yang telah tersedia seperti dari youtube, video, audio, gambar, infographic, dan layanan penyedia konten lainnya; dan (c) penyampaian media pembelajaran (content delivery) dapat berbantuan Learning Management System (LMS) seperti Edmodo, Moodle, Dokeos, Blackboard, dan banyak lagi layanan aplikasi LMS. (Handoko \& Waskito, 2018: 14-15).

Menurut Dewi dkk (2019), ada enam langkah untuk menerapkan blended learning dalam proses kegiatan pembelajaran tercapai dengan baik antara lain (1) menetapkan bahan ajar yang relevan untuk diterapkan sebagian secara tatap muka, online atau webbased learning. (2) menetapkan rancangan meliputi bagaimana materi ajar akan ditampilkan, mana yang menjadi inti pokok materi pembelajaran dan mana yang pengayaan, bagaimana siswa dapat mengakses, factor pendukung yang diperlukan misalnya perangkat lunak, tugas group atau mandiri (3) menetapkan format online. (4) melakukan uji rancangan. (5) pelaksanaan, dan evaluasi.

Perancangan pembelajaran tergantung dari tujuan pembelajaran yang akan diperoleh dan kompetensi dasar dalam proses pembelajaran. Dalam mengimplementasikan blended learning harus memperhatikan taksonomi Bloom untuk menyesuaikan antara tujuan pembelajaran, aktifitas pembelajaran dalam pengembangan bahan ajar (Handoko \& Waskito, 2018: 17). Mengingat pembelajaran adalah secara daring maka aktivitas digital harus mempunyai kesesuaian denga taksonomi digital Bloom
Desain pembelajaran (brief design) blended learning fisika dengan model flipped classroom dengan memperhatikan variasi tatap muka pembelajaran offline dan pembelajaran online dengan persentase 50\%-50\%. Pada kegiatan tatap muka dengan aktivitas yang beragam antara lain praktikum, diskusi, presentasi, tutor teman sebaya atau penjelasan-penjelasan yang berpusat kepada guru, umpan balik. Pada kelas online siswa dapat belajar independen tanpa terikat waktu misalnya mempelajari video pembelajaran, mengerjakan kuis interaktif, mengerjakan laboratorium virtual, mengerjakan soal-soal, pembuatan video presentasi, diskusi umpan balik.

Teori konstruktivisme dan teori belajar kognitif mendasari Pengembangan blended learning harus memperhatikan komponenkomponen system pembelajaran antara lain materi pembelajaran dari (a) sumber belajar yaitu, media offline, internet, komputer, program edukasi; (b penentu keberhasilan pencapaian tujuan adalah metode atau strategi; (c) media pembelajaran harus disesuaikan dengan tujuan dapat berbentuk audio visual, media cetak, media audio, komputer dan gabungan beberapa media (Dewi dkk, 2019: 41-42).

Menurut Bailey (2013) langkah-langkah blended learning implementation guide learning now seperti pada tabel 2. Digital learning now memberikan empat tahapan yaitu ciptakan kondisi untuk sukses (create condition for success, perencanaan (plan), melaksanakan (implement), dan perbaikan (improve). Pembelajaran ini memerlukan dukungan semua pihak, memerlukan perencanaan yang baik, memerlukan sarana-prasarana, komunikasi yang baik, budaya sekolah dan melakukan evaluasi secara berkala berkesinambungan. Selain dari dukungan tersebut pelaksanaan pembelajaran blended tidak terlepas dari aspek siswa itu sendiri antara lain independen learner belajar mandiri tergantung dari dirinya sendiri, berani membuat keputusan sendiri sahih dan terkini, mengenali kelemahan dan kelebihan diri, belajar dengan terhubung dunia luar tidak hanya menghafal, bertanggung jawab atas pembelajarannya sendiri dengan selalu memperbarui pengetahuan (kognisi), ketrampilan (psikomotorik) dan sikap (afektif), merefleksi atas pembelajarannya sendiri dan selalu menghubungkan tujuan pembelajaran dengan aplikasi didunia nyata, bertanggung jawab atas pembelajarannya sendiri (Abidin. Z, 2014: 47-48).

Mengacu pembelajaran pada makna pembelajaran blended sebagai dasar rancangan model desain pembelajaran blended learning 
maka dibuatlah setting atau desain pembelajarannya. Hal ini dilakukan untuk persiapan menghadapi pembelajaran tatap muka terbatas pada era kenormalan baru, untuk itu dilakukan penelitian dengan tujuan membuat desain model pembelajaran blended learning pada mata pelajaran fisika kelas XI MIPA semester 1 .

\section{Metode Penelitian}

Penelitian pengembangan bentuk penelitian R\&D dengan model ADDIE (Analysis, Design, Development, Implementation and Evaluation). Penelitian dilakukan di SMA negeri 1 Tempel, matapelajaran Fisika kelas XI pada bulan Maret s.d Mei 2021. Desain pembelajaran dirancang dalam rangka persiapan bulan Juli 2021 untuk pembelajaran tatap muka (PTM) terbatas pada era kenormalan baru. Tahapan penelitian ini hanya sampai pada tahap kedua yaitu analisa kebutuhan dan desain rancangan model blended learning. Design rancangan tersebut akan divalidasi oleh ahli media dan fisika dari Universitas. Teknik pengumpulan data menggunakan lembar observasi untuk memvalidasi rancangan pembelajaran blended, instrument penelitian berupa lembar observasi, analisa data secara kualitatif berdasar hasil obervasi. Perencanaan desain produk dengan menyusun desain pembelajaran blended dengan mengacu pada kompetensi matapelajaran fisika pada masa darurat C-19 dengan sintak blended learning. Kemudian disusun desain rancangan model pembelajaran blended learning berbantuan google classroom, telegram group dan e-modul lengkap dengan video pembelajaran, lab virtual, kuis interaktif.

Desain tersebut divalidasi oleh ahli media fisika yang merupakan dosen program studi pendidikan Fisikan Fakultas Sains dan Matematika Universitas Kristen Satya Wacana untuk selanjutnya disebut Validator A/Val A dan isi materi fisika oleh salah satu dosen FMIPA Jurusan Fisika di Universitas Negeri Yogyakarta untuk selajutnya disebut Validator B/Val B.
Instrumen validasi yang diberikan dengan mengisi kuesioner yang kemudian diolah, dianalisa dengan cara memberikan skor atau skala yang diperoleh dengan mengadopsi Skala Likert dengan skala Empat (Widoyoko, E.P. 2018: 200). Setiap aspek penilaian pada indikator atau pertanyaan dijumlahkan, kemudian jumlah skor penilaian dari setiap aspek dianalisis dalam bentuk presentase. standar penilaian skala 4 sehingga diperoleh standar penilaian dengan klasifiksi sebagai berikut (Widoyoko, E.P., 2018: 338).

Tabel 1. Standar Penilaian

\begin{tabular}{ll}
\hline \multicolumn{1}{c}{ Skor \% } & \multicolumn{1}{c}{ Kualifikasi } \\
\hline $85,01-100$ & Sangat Baik/ \\
& Sangat setuju \\
$70,01-85,0$ & Baik/Setuju \\
$50,01-70,0$ & Kurang Baik \\
$01,00-50,0$ & Tidak Baik \\
\hline
\end{tabular}

Penilaian desain pembelajaran secara umum dengan menjumlah pada setiap aspek kemudian direrata, hasil rerata disesuaikan dengan tabel di atas maka diperoleh hasil validasi. Penilaian desain pembelajaran blended yang dikembangkan bisa diujicobakan bila sudah memasuki klasifikasi baik.

\section{Hasil dan Pembahasan}

Diperlukan rancangan pembelajaran untuk mengatisipasi pembelajaran tatap muka (PTM) terbatas pada era kenormalan baru. Menggunakan strategi yang memadukan pembelajaran dalam jaringan atau online dan pembelajaran tatap muka terbatas, merupakan solusi yang efektif sehingga pembelajaran dapat dicapai dengan optimal. Desain pembelajaran (brief design) blended learning fisika dengan model flipped classroom dengan memperhatikan variasi tatap muka pembelajaran offline dan pembelajaran online dengan persentase 50\%$50 \%$. Detail tahapan perancangan pembelajaran seperti pada tabel 2.

Tabel 2. Desain Pembelajaran Blended

\begin{tabular}{|c|c|c|c|c|c|}
\hline & Analysis & Design & Development & Implementation & Evaluation \\
\hline 面 & $\begin{array}{l}\text { 1. Analisis KI- } \\
\text { KD. } \\
\text { 2. Analisis } \\
\text { kebutuhan } \\
\text { pembelaja- } \\
\text { ran. } \\
\text { 3. Identifikasi } \\
\text { sarana } \\
\text { pembelaja- } \\
\text { ran daring. }\end{array}$ & $\begin{array}{l}\text { 1. Merumuskan } \\
\text { tujuan } \\
\text { pembelajaran. } \\
\text { 2. Menentukan } \\
\text { indikator dan } \\
\text { kriteria penilaian. } \\
\text { 3. Merancang } \\
\text { pembelajaran. } \\
\text { 4. Merancang } \\
\text { strategi penilaian. }\end{array}$ & $\begin{array}{l}\text { 1. Mengembangkan } \\
\text { instrumen } \\
\text { penilaian. } \\
\text { 2. Mengembangkan } \\
\text { rancangan } \\
\text { pembelajaran. } \\
\text { 3. Mengembangkan } \\
\text { dan menyusun } \\
\text { materi dan } \\
\text { media. }\end{array}$ & $\begin{array}{l}\text { 1. Melaksanakan proses } \\
\text { pembelajaran. } \\
\text { 2. Memfasilitasi } \\
\text { interaksi guru-siswa- } \\
\text { sumber belajar. } \\
\text { 3. Memfasilitasi } \\
\text { keterlibatan siswa } \\
\text { (student } \\
\text { engagement). }\end{array}$ & $\begin{array}{l}\text { 1. Melakukan } \\
\text { monitoring } \\
\text { dan evaluasi. } \\
\text { 2. Mengumpul- } \\
\text { kan dan } \\
\text { mengolah } \\
\text { umpan balik. }\end{array}$ \\
\hline
\end{tabular}


Tabel 3. Alur desain (brief design) blended learning KD. 3.2, 4.2

\begin{tabular}{|c|c|c|c|c|c|}
\hline $\begin{array}{c}\text { Tujuan } \\
\text { Pembelajaran }\end{array}$ & $\begin{array}{l}\text { Kompetensi } \\
\text { Dasar }\end{array}$ & Penilaian & $\begin{array}{l}\text { Per- } \\
\text { temu } \\
\text { an ke }\end{array}$ & $\begin{array}{c}\text { Luring } \\
\text { On Classroom }\end{array}$ & $\begin{array}{c}\text { Daring } \\
\text { Off Clasroom }\end{array}$ \\
\hline \multirow{4}{*}{$\begin{array}{l}\text { Melalui proses } \\
\text { pembelajaran } \\
\text { materi sifat } \\
\text { elastisitas bahan } \\
\text { dengan } \\
\text { menggunakan } \\
\text { blended learning } \\
\text { berbasis proyek } \\
\text { (PjBL) dengan } \\
\text { model flipped } \\
\text { classroom } \\
\text { diharapakan } \\
\text { siswa dapat } \\
\text { berkolaborasi } \\
\text { dalam } \\
\text { menerapkan dan } \\
\text { melakukan } \\
\text { percobaan } \\
\text { tentang } \\
\text { elasitisitas bahan. } \\
\text { Terampil } \\
\text { merancang, } \\
\text { melakukan } \\
\text { percobaan, } \\
\text { menyajikan, } \\
\text { mengkomunikasi } \\
\text { kan hasil } \\
\text { percobaan dalam } \\
\text { bentuk laporan } \\
\text { tertulis dan } \\
\text { membuat, } \\
\text { mengunggah } \\
\text { video presetasi } \\
\text { percobaan }\end{array}$} & \multirow[t]{4}{*}{$\begin{array}{l}\text { 3.2 Menga } \\
\text { nalisis } \\
\text { sifat } \\
\text { elastisit } \\
\text { as } \\
\text { suatu } \\
\text { bahan } \\
\text { dalam } \\
\text { kehidu } \\
\text { pan } \\
\text { sehari- } \\
\text { hari } \\
\text { 4.2 Melaku- } \\
\text { kan } \\
\text { percoba } \\
\text { an } \\
\text { elastisit } \\
\text { as suatu } \\
\text { bahan }\end{array}$} & \multirow[t]{4}{*}{ 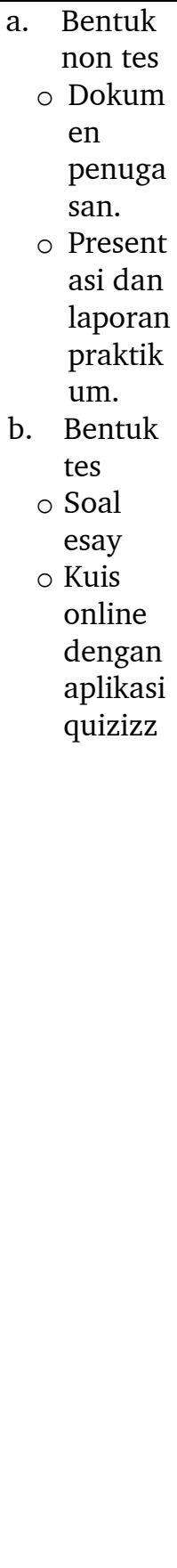 } & 1 & $\begin{array}{l}\text { Delivery e-modul KD } \\
\text { Isi: flipbook materi, } \\
\text { pembelajaran, kuis } \\
\text { Melakukan } \\
\text { percobaan } \\
\text { menentukan } \\
\text { koefisien elastisitas } \\
\text { pegas dan diskusi } \\
\text { Tatap muka }\end{array}$ & $\begin{array}{l}\text { 3.2, } 4.2 \\
\text { link lab virtual, video } \\
\text { interaktif, link kuis } \\
\text { Tugas: Belajar } \\
\text { Mandiri mendesain } \\
\text { perencanaan proyek } \\
\text { berkolaborasi secara } \\
\text { online (Desain a } \\
\text { plan for the project) } \\
\text { pegas seri dan } \\
\text { pararel dan } \\
\text { menyusun jadwal } \\
\text { (create a schedul). } \\
\text { Hasil dikirim } \\
\text { melalui google } \\
\text { classroom }\end{array}$ \\
\hline & & & 2 & $\begin{array}{l}\text { Umpan balik } \\
\text { perkembangan } \\
\text { proyek, diskusi, } \\
\text { tanya jawab } \\
\text { tentang pengaruh } \\
\text { gaya terhadap } \\
\text { panjang pegas } \\
\text { Tatap muka }\end{array}$ & $\begin{array}{l}\text { Tugas: membuat } \\
\text { laporan kegiatan } \\
\text { pembelajaran } \\
\text { berbasis proyek } \\
\text { sepert dalam } e^{-} \\
\text {modul. } \\
\text { Penugasan } \\
\text { Terstruktur PT }\end{array}$ \\
\hline & & & 3 & $\begin{array}{l}\text { Menghitung } \\
\text { konstanta pegas } \\
\text { seri -pararel }\end{array}$ & $\begin{array}{l}\text { Tugas: membuat } \\
\text { video tahapan } \\
\text { rancangan dan } \\
\text { pelaksanaan } \\
\text { percobaan. Video } \\
\text { diunggah ke } \\
\text { youtube, link } \\
\text { dikirimkan ke } \\
\text { telegram group } \\
\text { kelas }\end{array}$ \\
\hline & & & 4 & Penilaian tes esay & $\begin{array}{l}\text { Penilaian tes pilihan } \\
\text { ganda dengan } \\
\text { aplikasi Quizizz }\end{array}$ \\
\hline
\end{tabular}

Pada tabel 3 disajikan alur desain (brief design) blended learning penuh dengan model flipped classroom untuk satu kompetensi dasar (karena keterbatasan tempat disajikan contoh desain pembelajaran untuk satu kompetensi dasar dari empat kompetensi dasar mata pelajaran fisika untuk semester satu) Model pembelajaran blended learning pada tabel 3 adalah gabungan penuh antara pembelajaran tatap muka terbatas/on class dan kelas dalam jaringan atau online/off class, dimana kelas online tidak difungsikan untuk menggantikan kelas tatap muka. Desain pembelajaran (brief design) blended learning fisika dengan model flipped classroom dengan memperhatikan variasi tatap muka pembelajaran offline dan pembelajaran online dengan persentase $50 \%$ $50 \%$. 
Pada kegiatan tatap muka dengan aktivitas yang beragam antara lain praktikum, diskusi, presentasi, tutor teman sebaya atau penjelasanpenjelasan yang berpusat kepada guru, umpan balik. Kelas online merupakan kelanjutan yang terintegrasi dengan kelas tatap muka, misalnya mengerjakan tugas-tugas antara lain belajar mandiri mempelajari video pembelajaran, mengerjakan kuis interaktif, mengerjakan laboratorium virtual, mengerjakan soal-soal, pembuatan video presentasi, diskusi umpan balik tanpa dibatasi waktu dimanapun siswa berada karena e-modul dapat diakses, tugas mandiri terstruktur dan tugas mandiri tidak terstruktur sehingga pada kelas tatap muka mempunyai cukup waktu untuk berdikusi dan presentasi. Sehingga peran guru sebagai mediator, fasilitator, inisiator yang menggerakkan kelas tatap muka dan online (Handoko \& Waskito, 2018: 20-21).

Objek pembelajaran pada pembelajaran blended learning pada tabel 3 adalah teks, video, animasi, audio, gambar, simulasi, tugas, forum diskusi, kuis. Sesuai dengan definisi objek pembelajaran oleh IEEE sebagai semua entitas non digital maupun digital yang dapat digunakan untuk pembelajaran (Sumantri dkk, 2020: 10). Pengemasan teks untuk materi pembelajaran supaya menarik dan mudah digunakan dimanapun dengan menggunakan handphone digunakan e-modul yang berupa e-book dan flip book. semua materi ajar, soal-soal latihan dengan contoh pengerjaan, penjelasan materi pembelajaran dengan video pembelajaran, latihan soal dengan video, virtual lab dengan simulasi yang langsung di akses dengan link, kuis interaktif yang langsung dapat diketahui benar dan salahnya sertah nilai, dan link kuis akhir untuh mendapatkan feedback pencapaian pembelajaran.

Modul elektronik yang dibuat guru benarbenar harus lengkap dan menarik sehingga siswa dapat mempelajari, mengerjakan semua perintah dalam modul tanpa banyak kendala atau hambatan. Hal ini sangat penting sebagai upaya memperendah jumlah siswa menjadi prokrastinator akademik, walaupun hal ini bukan menjadi faktor tunggal tetapi efikasi diri siswa juga sangat mempengaruhi.

Pada aktivitas pembelajaran blended learning sangat perlu memperhatikan kata kerja operasional taksonomi Bloom domain digital, domain kognitif, domain afektif, domain psikomotorik dari mulai kompetensi dasar, tujuan pembelajaran, kegiatan pembelajaran untuk aktivitas tatap muka / on classroom dan aktivitas daring / online / off classroom.
Taksonomi Bloom domain digital yaitu aktivitas online pada tabel 3 adalah kuis online, (1) diskusi forum di telegram group pada dimensi mengingat, (2) dimensi memahami aktivitas online mengomentari diskusi di group telegram, memahami dan melaksanakan tugas, (3) dimensi menerapkan dengan aktivitas online dengan presentasi dalam video, pembuatan video, vlog, virtual lab / simulasi laboratorium (4) dimensi menganalisis dengan aktivitas online umpan balik tugas, presentasi, forum diskusi dalam group telegram, (5) dimensi evaluasi dengan aktivitas online yaitu berkolaborasi online, tanya jawab di forum telegram, (6) dimensi mencipta dengan aktivits online dengan menulis laporan penelitian, mendesain proyek.

Langkah selanjutnya adalah memvalidasi desain pembelajaran oleh ahli media dan fisika, teman sejawat sebelum diuji cobakan kepada siswa untuk pembelajaran pada era new normal dengan perpaduan tatap muka $50 \%$ dan daring $50 \%$. Aspek-aspek yang ditanyakan dalam kuesioner diadaptasi dari evaluasi proses pembelajaran daring dengan model evaluasi Kirkpatrick yaitu hasil untuk menetukan bahan pelajaran apakah sudah sesuai dengan tujuan pembelajaran atau belum, perilaku untuk melihat apakah siswa dapat mempraktekan apa yang telah dipelajari, pembelajaran apakah siswa memperoleh peningkatan pengetahuan, ketrampilan dan pengalaman belajar, reaksi untuk mengukur bagaiman tingkat kepuasan siswa (Kemendikbud, 2020: 57-60).

Hasil validasi evaluasi proses pembelajaran daring melalui desain pembelajaran blended learning pada tabel 4. Untuk penilaian pembelajaran blended learning dengan menggunakan teori yang dikemukakan oleh Smythe (2011) aspek-aspek utama dari blended learning adalah (a) aspek mode delivery yaitu perpaduan pembelajaran konvensional/ tradisional learning dan pembelajaran berbasis web/ web based online, (b) aspek teknologi yaitu perpaduan teknologi dan media (c) aspek pedagogi yaitu gabungan dari berbagai startegi pembelajaran (c) aspek kronologi yaitu pendekatan synchronous dan asynchronous. Aspek-aspek utama dari blended learning menjadi indikator instrumen kuesioner, hasil validasi penilaian desain pembelajaran blended learning pada tabel 5 .

Untuk penilaian pembelajaran blended learning dengan menggunakan teori yang dikemukakan oleh Smythe (2011) aspek-aspek utama dari blended learning adalah (a) aspek mode delivery yaitu perpaduan pembelajaran konvensional / tradisional learning dan 
pembelajaran berbasis web/web based online, (b) aspek teknologi yaitu perpaduan teknologi dan media (c) aspek pedagogi yaitu gabungan dari berbagai startegi pembelajaran (c) aspek kronologi yaitu pendekatan synchronous dan asynchronous. Aspek- aspek utama dari blended learning menjadi indikator instrumen kuesioner, hasil validasi penilaian desain pembelajaran blended learning pada tabel 5.

Tabel 4. Hasil validasi evaluasi proses pembelajaran daring melalui desain pembelajaran blended

\begin{tabular}{|c|c|c|}
\hline Indikator & $\begin{array}{r}\text { Skor } \\
\text { Val A }\end{array}$ & $\begin{array}{r}\text { Skor } \\
\text { Val B }\end{array}$ \\
\hline \multicolumn{3}{|l|}{ Strategi Pembelajaran } \\
\hline $\begin{array}{l}\text { Interaksi dalam proses } \\
\text { pembelajaran disiapkan dengan } \\
\text { baik. }\end{array}$ & 3 & 4 \\
\hline $\begin{array}{l}\text { Penjawalan disiapkan dengan } \\
\text { lengkap dan jelas. }\end{array}$ & 4 & 4 \\
\hline $\begin{array}{l}\text { Materi pembelajaran disiapkan } \\
\text { dengan jelas, mudah diakses, } \\
\text { mudah dipahami. }\end{array}$ & 3 & 4 \\
\hline $\begin{array}{l}\text { Metode pembelajaran mudah } \\
\text { diikuti. }\end{array}$ & 3 & 4 \\
\hline $\begin{array}{l}\text { Guru memberi kesempatan } \\
\text { mengeklporasi materi secara } \\
\text { mandiri. }\end{array}$ & 3 & 3 \\
\hline
\end{tabular}

\begin{tabular}{lll}
\hline Kualitas Materi Ajar & & \\
\hline $\begin{array}{l}\text { Materi ajar yang digunakan } \\
\text { menambah pengetahuan dan }\end{array}$ & 3 & 3 \\
$\begin{array}{l}\text { keterampilan. } \\
\text { Tugas dan asesmen relevan }\end{array}$ & 3 & 3 \\
$\begin{array}{l}\text { dengan materi ajar yang } \\
\text { diberikan. }\end{array}$ & & \\
$\begin{array}{l}\text { Materi ajar mudah diakses. } \\
\text { Materi ajar jelas dan mudah } \\
\text { dipahami. }\end{array}$ & 3 & 3 \\
\end{tabular}

\begin{tabular}{lll}
\hline Student Engagement & & \\
\hline Membuat siswa tertarik & 4 & 4 \\
Siswa menambah pengetahuan & 4 & 4 \\
dan ketrampilan melalui & & \\
pembelajaran tatap muka -online & &
\end{tabular}

\section{Ketercapaian Tujuan Pembelajaran}

Proses pembelajaran dan materi 344 ajar akan meningkatakan soft skill, pengetahuan, norma akdemik siswa.

\section{Jumlah skor}

$39 \quad 43$

Tabel 5. Hasil validasi penilaian desain pembelajaran blended learning

\begin{tabular}{lcc}
\hline \multicolumn{1}{c}{ Indikator } & $\begin{array}{r}\text { Skor } \\
\text { Val A }\end{array}$ & $\begin{array}{c}\text { Skor } \\
\text { Val B }\end{array}$ \\
\hline Mode delivery & & \\
\hline $\begin{array}{l}\text { Terdapat kombinasi } \\
\text { pembelajaran tatap muka } \\
\text { dan daring. }\end{array}$ & 4 & 4 \\
\end{tabular}

\begin{tabular}{lll}
\hline Teknologi \\
\hline $\begin{array}{l}\text { Menggunakan media dan } \\
\text { teknologi. }\end{array}$
\end{tabular}

\section{Pedagogi}

\begin{tabular}{lll}
\hline Terdapat kombinasi & 3 & 4 \\
pendekatan pembelajaran. & &
\end{tabular}

\begin{tabular}{lcc}
\hline Kronologi & & \\
\hline $\begin{array}{l}\text { Terdapat pendekatan } \\
\text { synchronous (realtime). }\end{array}$ & 3 & 3 \\
$\begin{array}{l}\text { Terdapat pendekatan } \\
\text { asynchronous. }\end{array}$ & 3 & 3 \\
\hline Jumlah Skor & $\mathbf{1 7}$ & $\mathbf{1 8}$ \\
\hline
\end{tabular}

Untuk penilaian objek pembelajaran mengadaptasi dari LORI (Learning Object Review Instrument) berpusat pada sembilan aspek, yakni: kualitas konten, sesuai dengan tujuan pembelajaran, umpan balik dan adaptasi, motivasi, desain presentasi, mudah dipelajari/usabilitas interaksi, mudah diperoleh/ aksesabilitas, kemampuan sistem/reusabilitas, dan patuh pada aturan (Kemendikbud, 2014: 2226). Untuk hasil validasi desain penilaian objek pembelajaran dapat dilihat pada tabel 6 .

Berdasar tabel 4, 5, dan 6 apabila jumlah skor penilaian hasil validasi desain pembelajaran blended learning oleh ahli media fisika (validator A/Val A) dan ahli isi materi fisika (validator B/ Val B) dianalisis dalam bentuk presentase diperoleh penilaian sebagai berikut. Penilaian untuk kuesioner evaluasi proses pembelajaran daring oleh ahli media fisika adalah 81,25\% masuk kategari cukup baik, dan oleh ahli isi materi fisika 89,58\% masuk kategori sangat baik. Penilaian desain pembelajaran blended learning oleh ahli media fisika adalah $85 \%$ masuk kategari setuju dan oleh ahli isi materi fisika 90\% masuk kategori sangat setuju. 
Tabel 6. Hasil validasi penilaian objek pembelajaran

\begin{tabular}{rrr}
\hline Indikator & Skor & Skor \\
& Val A & Val B \\
\hline
\end{tabular}

Kualitas konten

\begin{tabular}{lll}
\hline $\begin{array}{l}\text { Struktur materi jelas, tercantum } \\
\text { kompetensi dasar, kegiatan }\end{array}$ & 4 & 4 \\
$\begin{array}{l}\text { pembelajaran. } \\
\begin{array}{l}\text { Terdapat pengantar, penjelasan. } \\
\text { Disajikan dalan bahasa yang }\end{array}\end{array}$ & 3 & 3 \\
$\begin{array}{l}\text { jelas, lengkap komunikatif, } \\
\text { terdapat tautan untuk } \\
\text { meperkayan konten. }\end{array}$ & 3 \\
$\begin{array}{l}\text { Terdapat ragam obyek } \\
\text { pembelajaran (Teks, gambar, } \\
\text { audio, video, animasi, simulasi). }\end{array}$ & 3 & 3 \\
$\begin{array}{l}\text { Terdapat soal latihan dan contoh } \\
\text { mengerjakan soal. }\end{array}$ & 4 & 3 \\
$\begin{array}{l}\text { Tercantum referensi daring dan } \\
\text { luring. }\end{array}$ & 4 & 3 \\
$\begin{array}{l}\text { Tampilan visual jelas, dan teks } \\
\text { mudah dipelajari. }\end{array}$ & 3 & 3 \\
\hline Keselarasandengan tujuan & & \\
\hline
\end{tabular}

\section{Keselarasan dengan tujuan} pembelajaran

\begin{tabular}{lll}
\hline $\begin{array}{l}\text { Evaluasi sesuai tujuan } \\
\text { pembelajaran. }\end{array}$ & 3 & 4 \\
$\begin{array}{l}\text { Aktivitas belajar sesuai dengan } \\
\text { tujuan pembelajaran. }\end{array}$ & 3 & 4 \\
$\begin{array}{l}\text { Karakteristik siswa sesuai dengan } \\
\text { tujuan pembelajaran. }\end{array}$ & 3 & 3 \\
\hline
\end{tabular}

\begin{tabular}{lcc}
\hline Umpan balik & & \\
\hline $\begin{array}{l}\text { Aktivitas pembelajaran sesuai } \\
\text { kebutuhan siswa. }\end{array}$ & 3 & 3 \\
\hline Motivasi & & \\
\hline $\begin{array}{l}\text { Konten menarik sehingga } \\
\text { memotivasi untuk belajar. }\end{array}$ & 4 & 4 \\
\hline Desain presentasi & & \\
\hline $\begin{array}{l}\text { Desain menarik dan efektif. } \\
\begin{array}{l}\text { Teks terlihat jelas dan mudah } \\
\text { dibaca. }\end{array}\end{array}$ & 3 & 4 \\
$\begin{array}{l}\text { Gambar dan grafik diberikan } \\
\text { label, dan terlihat jelas. }\end{array}$ & 3 & 4 \\
Fitur dekoratif, tata warna, & 3 & 3
\end{tabular}

musik, scara estetik menarik.

\section{Usabilitas interaksi}

Desain antarmuka (interface) 33

jelas dan ada instruksi jelas untuk

memandu.

\section{Aksebilitas}

Dapat diakses mudah.

$3 \quad 3$

\section{Reusabilitas}

Sumber belajar mandiri, dapat

digunakan beberapa topik dan

konteks pembelajaran lain tanpa

banyak modifikasi.

\section{Jumlah Skor}

$62 \quad 65$

Penilaian untuk objek pembelajaran oleh ahli media fisika oleh ahli media fisika adalah $81,58 \%$ masuk kategori setuju dan oleh ahli isi materi fisika $85,52 \%$ masuk kategori sangat setuju. Desain pembelajaran blended yang dikembangkan bisa diuji cobakan karena sudah memasuki klasifikasi baik (mendekati sangat baik). Diharapkan dalam pembelajaran tercapai keterlibatan siswa (student engagemnet) yang tinggi karena pengajaran menjadi efektif, siswa aktif, minat siswa tinggi karena aneka sumber belajar dapat memotivasi siswa (Kusyanti. R.N, 2021: 320).

Komentar dan saran dari ahli isi materi fisika terhadap objek pembelajaran ada objek yang memerlukan perbaikan antara lain: gambar, persamaan-persamaan dan tabel perlu diurutkan penomorannya, beberapa ada yang salah dalam pengetikan, untuk isi materi fisika tidak ada yang salah konsep. Perlu digunakan tata Bahasa Indonesia yang baku. Penggunaan kata depan dan kata sambung masih rancu. Saran dan komentar dari ahli media fisika supaya di buat dengan tabel tersendiri khusus rancangan aktivitas pembelajaran synchronous dan a synchronous, untuk setiap kompetensi dasar. Pembelajaran synchronous atau sinkron dibedakan antara sinkron langsung dan sinkron maya.

\section{Simpulan dan Saran}

Berdasar tabel hasil penilaian kualifikasi dapat diperoleh bahwa rerata aspek atau indikator masing-masing ahli media fisika adalah $82,61 \%$ dan ahli materi fisika $88,37 \%$, sehingga diperoleh rerata $85,48 \%$ maka hasil validasi ahli evaluasi proses pembelajaran daring, desain pembelajaran blended learning dan penilaian objek pembelajaran desain pembelajaran blended yang dikembangkan bisa diuji cobakan karena sudah memasuki klasifikasi baik (mendekati sangat baik). Sehingga hasil desain pembelajaran blended sudah layak untuk diuji cobakan oleh guru fisika pada pembelajaran di era kenormalan baru meskipun terdapat beberapa hal perlu perbaikan dan kesimpulan akhir dari ahli media dan isi materi adalah desain pembelajaran blended dapat digunakan dengan revisi. Saran untuk penelitian berikutnya supaya menguji cobakan desain pembelajaran blended pada mata pelajaran fisika kelas XI semester 1 sampai pada tahapan evaluasi.

\section{Daftar Pustaka}

Abidin, A. (2014). Garis panduan Amalan Terbaik Konsep pembelajaran Teradun Bagi Politeknik-Politeknik Malaysia. Putrajaya: 
Bahagian Instruksional dan Pembelajaran Digital Jabatan Pengajian Politeknik.

Alammary, A. (2019). Blended Learning models for introductory programming courses: A systematic review. PLOS ONE, 14(9), 1-26. https://doi.org/10.1371/journal.pone.0221 765

Bailey, J.E dkk. (2013). Navigating The Digital Shift: Implementation Strategies for Blended and Online Learning. Websites: Digital Learning Now.com GettingSmart.com

Dewi, C. K dkk. (2019). Blended Learning Konsep dan Implementasi pada pendidikan Tinggi Vokasi. Bali: Swasta Nulus.

Direktorat Pembelajaran. Direktorat jendral Pembelajaran dan Kemahasiswaan Kementrian Riset, Teknologi, dan Pendidikan Tinggi. (2017). PEDATI Model Desain Pembelajaran Blended.

Handoko \& Waskito. (2018). Blended Learning Teori dan Penerapannya. Padang: LPTIK.

Kusyanti. R.N. (2021). Hubungan Antara Sres Akademik dan Student Engagemnet Siswa SMA pada Masa pandemi Covid-19.
Ideguru: Jurnal Karya Ilmiah Guru, 6(3), 315-320.

https://doi.org/10.51169/ideguru.v6i3.276

Oktaria, D. S dkk. (2018). Model Blended Learning. Jakarta: Halaman Moeka.

Rusman, K, \& Riyana, C (2012). Pembelajaran Berbasis Teknologi Informasi dan Komunikasi: Mengembangkan profesionalitas guru. Jakarta: Rajagrafindo Persada.

Smythe, M. (2011). Blended learning: A Transformative process?

Paper presented at the National Tertiary Learning and Teaching Conference 2011, Nelson, New Zealand. From https://www.academia.edu/15663193/Ble nded_learning_A_transformative_process

Stein, Jared \& Graham, Charles R. (2014). Essentials for Blended Learning. New York: Routledge.

Sumantri, A dkk. (2020). Booklet Pembelajaran Daring. Jakarta: Kemendikbud RI.

Widoyoko, E. P. (2018). Penilaian Hasil belajar di Sekolah. Yogyakarta: Pustaka Pelajar. 